\title{
Relationship between Unsafety Action and Unsafe Conditions with Traffic Accidents in Passenger Car Driversat Meulaboh Type C Terminal
}

\author{
${ }^{1}$ Ishalyadi, ${ }^{1}$ Muhammad Iqbal Fahlevi, ${ }^{1}$ Susy Sriwahyuni, ${ }^{1}$ Yolanda Oktaria \\ ${ }^{1}$ Faculty of Public Health, Universitas Teuku Umar, Aceh, Indonesia \\ Coresponding author: Ishalyadi, e-mail: ishalyadi@utu.ac.id \\ Co-author :MIF:fahlevi@utu.ac.id, SS: susysriwahyuni@utu.ac.id, YO: yolanda19k3@gmail.com \\ Submitted:20/08/2020 Revised:02/09/2020 Accepted:19/10/2020 Published online: 21/10/2020
}

doi: https://doi.org/10.35308/j-kesmas.v7i2.1646 How to cite this article: Ishalyadi, I.,Fahlevi, M.I., Sriahyuni, S.,\& Oktaria, Y. (2020). Relationship between Unsafety Action and Safety Condition with Traffic Accidents in Passenger Car Drivers at Meulaboh Type C Terminal. J-Kesmas: Jurnal Fakultas Kesehatan Masyarakat (The Indonesian Journal of Public Health), 7(2), 63-67.

\begin{abstract}
Traffic accidents according to the World Health Organization are unexpected events that cause injury, damage, and also loss to the owner (victim) and can cause death or injuries both minor injuries and serious injuries. The number of passenger car accidents from Aceh Barat to Banda Aceh through the lane Aceh Barat - Aceh Jaya crossing is high from 2018 with 62 cases (63.86\%) and 2019 with 64 cases (65.92\%) from January to January August. The high number of cases was influenced by driver fatigue, unsafety condition, unsafety action, length of service and vehicle eligibility. The purpose of this study was to determine the relationship of fatigue, unsafety condition, unsafety action, years of service as well as the eligibility of vehicles with traffic accidents on the driver of passenger cars in Meulaboh type $\mathrm{C}$ terminal. This type of research is quantitative research using cross sectional. The sample method used is total sampling, that is, all populations used as the study sample are all passenger car drivers in the Meulaboh type $\mathrm{C}$ terminal, amounting to 48 people. The analysis used is univariate analysis and bivariate analysis. The results showed that there was a relationship between unsafety condition and unsafety action with traffic accidents, which was $\mathrm{P}$ value $<0.05$. Here by it is suggested to the transportation department, the traffic unit, the land transportation organization to cooperate with each other in providing information about factors relating to traffic accidents as well.
\end{abstract}

Keywords: UnsafetyCondition, Unsafety Action, Driver, Traffic Accident.

\section{Introduction}

Clean water Traffic accidents are a risk that is a problem for everyone in the world. Injuries to death occur suddenly and unexpectedly. As a result of these accidents can destroy the life of someone who experienced the accident, there are even some people who experience a sense of trauma. Another impact resulting from the traffic accident is the loss of productivity, depression and even lead to suicide .Every year traffic accidents in Indonesia have increased. The large number of accidents is related to the increasing number of vehicles, both types of motorized vehicles and passenger vehicles (Hidayati, et al., 2016). Every traffic accident is usually caused by several factors that arise such as human factors, vehicle factors, road / environmental factors or a combination of these factors (Marsaid, et al., 2013).

The human factor is caused by the lack of knowledge of drivers about driving safety while driving. Low knowledge will affect one's actions. (Husna, et al., 2020). Based on age, traffic accidents show that about $20 \%$ of the drivers involved in accidents are drivers who are under 17 years of age.
Of course this can be thought of considering that new drivers can have a SIM at the age of 17 years, while quite a lot of drivers involved in accidents under 17 years. (Putri, 2014)

National Highway Transportation Safety Board (NHTSA), states that there are 6 main causes of accidents, namely the driver loses concentration $(55 \%)$, tired and sleepy (45\%), under the influence of drugs or alcohol $(30 \%)$, speed exceeds the limit ( $30 \%)$, weather $(15 \%)$, and damaged components (1014\%). Traffic accidents in 2013 became one of the causes of death in the world, as many as 1.24 million people die each year. And calculated for the number of times per day as many as 3,397 people died in the world. And almost $90 \%$ of these deaths occur in low and middle income countries. If no immediate action is taken, it is estimated that the number of victims resulting in death will increase to 1.9 million by 2020 (Rifal, 2015).

The human factor still plays the biggest role in traffic accidents, contributing $95 \%$ and $94 \%$ respectively to accidents that occur in the United Kingdom and America. In Indonesia, it is estimated 
that human error factors are still the main cause, namely the driver loses concentration (55\%), tired and sleepy (45\%), under the influence of drugs or alcohol (30\%), speed exceeds the limit (30\%), weather (15\%), and damaged components (10-14\%). (Zuraida, 2020). Driver fatigue can also cause accidents while driving. The level of fatigue is a relationship with a traffic accident. (Herdiyana, 2019)

The Republic of Indonesia National Police states that every year there are 28,000 - 38,000 people die from traffic accidents in Indonesia. Where traffic accidents also have an impact on increasing poverty, because traffic accidents cause maintenance costs, loss of productivity, loss of breadwinners in the family (Abdullah, 2014)

Based on data from the West Aceh Regional Police Traffic Unit, the number of accidents in West Aceh from 2018 was 48 cases in passenger cars and in 2019 through September 39 cases of passenger cars were involved in traffic accidents (SATLANTAS Aceh Barat, 2019). Whereas in Aceh Jaya, based on data from the Aceh Police Unit, the number of passenger car accidents from Aceh Barat to Banda Aceh via the Aceh Barat - Aceh Jaya crossing is high from 2018 there were 62 cases $(63.86 \%)$ cases of passenger cars from Aceh Barat and in 2018 it increased to $64(65.92 \%)$ cases of accidents. And passenger transportation involved in traffic accidents in 2018 consists of 31 transportation where 19 people died, 6 people were seriously injured and 63 people were slightly injured. And in 2019 passenger transportation involved in accidents then increased to 37 transportation where 27 people died, 12 people were seriously injured and 91 people were slightly injured (SATLANTAS Aceh Jaya, 2019).

\section{Materials and Methods}

This research uses a quantitative method with Cross Sectional approach which is a type of research that emphasizes the measurement time at one time at a time or the same day which is done on the dependent variable and the independent variable. The dependent variable is a traffic accident while the independent variable is an unsafe condition and safe action. This approach is used to see the relationship between one variable with another variable.

This research was conducted at the Type C Terminal Meulabohkecamatan Johan Pahlawan as a place of arrival and departure of the driver and passengers located in West Aceh, Aceh province. The time of the study was conducted on 2-14 November
2019.

The population in this study were all passenger car drivers from 8 counters in Terminal type $\mathrm{C}$ Meulaboh. The method of sampling in this study is the total sampling method, namely the sampling is done in a whole way that is the entire sample of research samples on 48 drivers.

\section{Results}

\section{Univariate Analysis}

Based on Table 1 it is known that of the 48 respondents whose safety conditions were safe as many as 30 respondents $(62.5 \%)$ while those whose safety conditions were not safe were 18 respondents $(37.5 \%)$.

Table 1. Frequency distribution based on unsafety condition of respondents withTraffic accidents

\begin{tabular}{lcc}
\hline Unsafety condition & Frequency & $\mathbf{( \% )}$ \\
\hline Safe & 30 & 62,5 \\
\hline Unsafe & 18 & 37,5 \\
\hline \multicolumn{1}{c}{ Total } & $\mathbf{4 8}$ & $\mathbf{1 0 0}$ \\
\hline
\end{tabular}

Based on Table 2 it is known that of the 48 respondents whose safety actions were safe were 23 respondents $(47.9 \%)$ while those whose safety actions were not safe were 25 respondents $(52.1 \%)$.

Table 2. Frequency distribution based on Unsafety action of respondents withTraffic accidents

\begin{tabular}{lcc}
\hline \multicolumn{1}{c}{ Unsafety action } & Frequency & $\mathbf{( \% )}$ \\
\hline Safe & 23 & 47,9 \\
\hline Unsafe & 25 & 52,1 \\
\hline \multicolumn{1}{c}{ Total } & $\mathbf{4 8}$ & $\mathbf{1 0 0}$ \\
\hline
\end{tabular}

\section{Bivariate Analysis}

Bivariate analysis to determine the relationship between the independent variable and the dependent variable. This test uses a chi-square test, if there is a statistically significant relationship, a $p$ value $<0.05$ is obtained.

Based on Table 3. it is known that there are as many as 27 (90\%) drivers whose unsafety conditions are safe have experienced an accident, conversely among the drivers whose unsafety conditions are unsafe, there are 16 (88.9\%) who have never experienced a traffic accident. This is in accordance with the chi square statistical test obtained value of Pvalue $=0,000$ and this is smaller than $\alpha=0.05$ ( $\mathrm{P}$ value $=0.000<=\alpha 0.05)$, where $\mathrm{Ha}$ is accepted and 
Ho is rejected so it can be concluded that there is a relationship between unsafety condition with traffic accidents on passenger car drivers in the Meulaboh type $\mathrm{C}$ terminal.
From the analysis results obtained OR value $=$ 0.014, meaning that drivers whose unsafety conditions are not safe (safe driver's actions) in driving a passenger car are not at risk in experiencing a traffic accident.

Table 3. Relationship between unsafety action and traffic accident

\begin{tabular}{|c|c|c|c|c|c|c|c|c|}
\hline \multirow{3}{*}{ Unsafety action } & \multicolumn{4}{|c|}{ Traffic accident } & \multirow{2}{*}{\multicolumn{2}{|c|}{ Total }} & \multirow{3}{*}{$\mathbf{p}_{\text {value }}$} & \multirow{3}{*}{ OR $(95 \% \mathrm{CI})$} \\
\hline & \multicolumn{2}{|c|}{ Ever } & \multicolumn{2}{|c|}{ NoEver } & & & & \\
\hline & $\mathbf{F}$ & $\%$ & $\mathbf{F}$ & $\%$ & $\mathrm{~F}$ & $\%$ & & \\
\hline Safe & 21 & 91,3 & 2 & 8,7 & 23 & 100 & 0,00 & 22,313 \\
\hline
\end{tabular}

\section{Discussion}

\section{Relationship between unsafety condition of drivers and traffic accidents}

Based on the chi square statistical test results obtained $\mathrm{p}$ value $=0.00$ and this is smaller than $\alpha=$ 0.05 (Pvalue $=0.00<\alpha=0.05$ ) so that there is a significant relationship between unsafety condition and past accident crossing on mopen (passenger car) drivers at the type $\mathrm{C}$ meulaboh terminal. From the analysis results obtained OR value $=0.014$, meaning that drivers whose unsafety conditions are not safe (safe driver conditions) in driving a passenger car are not at risk in having a traffic accident compared to drivers whose unsafety conditions are not safe (unsafe driver conditions).

Based on the findings of researchers in the field that respondents whose safety conditions are safe when driving a passenger car will have an effect and is directly proportional to traffic safety, one's attention to the unsafety condition of the driver and its passengers affect the safety of the driver and passenger. Meanwhile, if the unsafety condition will affect the level of safety in driving, Unsafety condition is an unsafe and dangerous condition for workers. Therefore, the existence of unsafety conditions that are safe in driving aims to minimize or eliminate the number of traffic accidents.

According to Heinrich's theory in Suwardi, et al., (2018) that, the cause of an accident consists of 2 causes, namely unsafety action and unsafety condition, and the key to preventing accidents is to eliminate unsafe attitude and conditions.

The results of this study indicate that there is a significant relationship between unsafety conditions and traffic accidents on passenger car drivers in the Meulaboh type $\mathrm{C}$ terminal. The results of this study are the same as the results of a study conducted by Kairupan, et al., (2019), on online motorcycle taxi drivers where there is an unsafety condition relationship with work accidents on online motorcycle taxi and base motorcycle taxi in the city of Manado with Pvalue $=0.022$.

The results of this study are also the same as the results of a study conducted by Sari, et al., (2015), in truck drivers thanks to the gift where there is a relationship between the driver's condition and the traffic accidents in the truck driver at PT Belawan beam sustainable gift with a value of Pvalue $=0.001$. This study is also in line with research conducted by Sriwahyuni, et al., (2020), that unsafe conditions also affect the accident rate.

\section{The Relationship between Unsafety Action Drivers and Traffic Accidents}

Based on the results of the chi square statistical test in the value of Pvalue $=0.00$ and this is smaller than $\alpha=0.05$ (Pvalue $=0.00<\alpha=0.005$ ) so that there is described a significant relationship between unsafety action with traffic accidents on the driver mopen (passenger car) in the type $\mathrm{C}$ terminal meulaboh. From the results of the analysis also obtained the value of $\mathrm{OR}=22.313$ means that the driver with unsafety action is safe (unsafe driver action) while driving has 22.313 times the chance to experience a traffic accident compared to the driver whose unsafety action is unsafe (safe driver action).

Based on the findings of researchers in the field that respondents whose unsafety action is not safe when driving a passenger car will have an effect and is directly proportional to traffic safety, one's attention to the unsafety action of the driver and his passengers influence the safety of the driver and passenger. Whereas if the unsafety action is not safe it will affect the level of safety in driving such as the action of the driver who smokes while driving, the driver who precedes other vehicles from the left lane and the driver who drives the vehicle over $60 \mathrm{~km} /$ hour and many more of the unsafety action which is dangerous for driver

Unsafety action is an unsafe and dangerous action for workers. Therefore it is very necessary 
unsafety action that is not safe in driving aims to minimize or eliminate the number of traffic accidents. Unsafety Action, such as carelessness, disobeying work procedures or violating traffic signs, not using personal protective equipment (PPE), not taking care of a vehicle driving license, etc. are very dangerous and when the danger comes can cause harm both material losses or soul. Unsafety action is also an unsafe act carried out by the driver. (Pratama, 2016)

Likewise the driver's carelessness, which is doing other activities while driving which results in the disruption of the driver's concentration, for example driving a car recklessly, lighting a cigarette, driving while using a cellphone and chatting with passengers. (Utomo, 2012)

The results of this study indicate that there is a relationship between unsafety action with traffic accidents on the passenger car driver at the Meulaboh type $\mathrm{C}$ terminal. The results of this study are the same as the results of research conducted by Rifal (2015), on PO Jember Indah bus drivers that there is a relationship between the actions of drivers with traffic accidents on beautiful PO jember bus drivers with a value of Pvalue $=0.006$.

The results of this study are also the same as the results of a study conducted by Noviandi (2017), on bus drivers in the Jember-Kencong-Lumajang route where there is a relationship between the actions of the driver and traffic accidents on the Jember-Kencong-Lumajang bus route driver with a Pvalue $=0.027$.

The results of research conducted by Guritnaningsih, et al., (2012), said that human error in vehicle drivers is caused by recognition errors and decision errors. The negligence factor in recognizing and interpreting the situation on the road, the surrounding environment conditions that are less supportive, the knowledge to master the vehicle in an emergency has led to negligence in making the right decision, and then manifesting it in safe driving / driving.

\section{Conclusion}

There is a significant relationship between unsafety Condition, unsafety action with traffic accidents on passenger car drivers in the type $\mathrm{C}$ terminal Meulaboh with a value of Pvalue on these 2 variables: 0,000 and $\mathrm{OR}, 0.014$ on the unsafety condition variable and 22,313 on the unsafety action variable. It is recommended to the government to be able to increase the commitment in supervision, to the announcement so that they are always compliant with traffic signs and do not use hand phon when driving.

\section{Acknowledgement}

This research was carried out well because of help from other parties. Thank you to the aceh west and acehjaya traffic units and also to the aceh west aceh passenger car organization which helped in completing this research.

\section{Author Contribution and Competing Interest}

All of the authors contributed in collecting and analyzing the data, including preparing the manuscript. The author assures thet there is no conflict of interest in the activities and preparation of this report.

\section{Publisher's Note}

J-Kesmas: JurnalFakultas Kesehatan Masyarakat (Indonesia Journal of Public Health) remains neutral with regard to jurisdictional claims in published institutional affiliation.

\section{References}

Abdullah, I.R. (2014) Risk factors of traffic accident incidents in the bentor in the limboto district police of gorontalo regency 2007-2009. Jurnal Masyarakat Epidemiologi; 2(2),108-112

Chrussiawanti. (2015) Relationship between the level of knowledge and the use of safety riding in high school 2 sukoharjo youth (Skripsi) ; STIKES Kusuma Husada Surakarta

Guritnaningsih,T. (2018) Human failure (human error) in traffic accidents: analysis based on information processing. Journal of Indonesia Road Safety ; 1(1), 30-38

Hidayati, A \& Hendrati, LY. (2016) Risk analysis of traffic accidents based knowledge, use of path, and speed drive. JurnalBerkalaEpidemiologi; 4 (2), 275-287

Herdiyana, R (2019) The effect of driving time duration factors on the level of driving outcomes in rest area determination. Jurnal Pusjatan; 17 (2), 1-15

Husna,A \& Fahlevi, MI. (2020). The implementation of sadari in the early detection of breast cancer 
in young women high school of west aceh regency. J-Kesmas JurnalFakultas Kesehatan Masyarakat; 7(1), 51-56

Kairupan, Felly A \& Doda, D. (2019) Relationship between unsafe action and unsafe condition with work accidents on online ojek and ojek pangkalan in the city of Manado. Jurnal KESMAS; 8(6)

Marsaid, H., \&Ahsan. (2013) factors related to the events of accidents Traffic in motorcycle drivers in the polres areaMalang district. JurnalllmuKeperawatan; 1(2), 1-15

Noviandi. (2017) Factors affecting unsafe driving behavior on jember-kencong-lumajag route bus drivers. JurkesPolije; 2 (5), 121-128

Rifal.(2015) Risk factors related to traffic accidents in bus drivers (study on bus p.o. jemberindah route jember-situbondo) (thesis). Jember; Jember University

Ratanto. 2018. Analisis Faktor yang Berhubungan dengan Kecelakaan laluLintas di Samarinda; 2(4), 166-175

Putri,CE. (2014) Characteristic analysis of accidents and causes factors accidents in the blackspot location in kayu agung city. Jurnal Teknik Sipil dan Lingkungan; 2(1), 888-891
Sari., Windy P., Mahyuni, EL \& Salamah, U (2015) Factors that influence the potential for workplace accidents in truck drivers at PT bless blessing belawan. Jurnal USU; 1(2), 1-12

Sriwahyuni, S., Santika, E., Khairunas, Ishalyadi, \&Fahlevi MI. (2020). The effect of work situation and unsafety action on work accident in pt. Raja marganaganraya district. J-Kesmas JurnalFakultas Kesehatan Masyarakat; 7(1), 35-37

Satuan Lalu Lintas [SATLANTAS]. 2019. Data of Traffic Accidents in Aceh Jaya Regency : Aceh jaya.

Satuan Lalu Lintas [SATLANTAS]. 2019. Data of Traffic Accidents in Aceh Jaya Regency : Aceh Barat

Utomo, N. (2012) Analysis of factors causing traffic accidents on segment road by-pass krian balongbendo ( $\mathrm{km} 26+000-\mathrm{km} 44+520)$. Jurnal Teknik Sipil KERN; 2 (2). 234-239

Utami, TN \&Nuraini. (2020). The Design of the Role Model of Working Women (Occupational Health Perspective). J-Kesmas: JurnalFakultas Kesehatan Masyarakat; 7(1), 777-780

Zuraida, R. (2015). Fatigue risk of long-distance driver as the impact of the duration of work. ComTech; 6 (3), 319-328 